\title{
Karakteristik Petani Milenial pada Kawasan Sentra Padi di Jawa Barat
}

\section{Characteristics of Millenial Farmers in Rice Center Area in West Java}

\author{
Yoyon Haryanto*), Lukman Effendy, Detia Tri Yunandar
}

Politeknik Pembangunan Pertanian Bogor, Jawa Barat - BPPSDMP Kementerian Pertanian

${ }^{*}$ E-mail korespondensi: yoyonharyanto@gmail.com

Diterima: 8 Agustus 2021 | Disetujui: 15 Desember 2021 | Publikasi Online: 22 Desember 2021

\begin{abstract}
The presence of millennial farmers provides an alternative in accelerating the regeneration of farmers. Millennial farmers are considered capable of bridging young farmers with farmers who have been farming for a long time. However, the trend in the field has not seen the specific character possessed by millennial farmers. The purpose of this study was to described the main characteristics of millennial farmers and analyzed the factors that influence the character formation of millennial farmers. The study used a survey design with cluster random sampling technique, obtained 63 respondents representing millennial farmers in the rice center zone in three districts in West Java. Data processing used descriptive techniques and Partial Least Square The results of the study showed that the character of millennial farmers has individual characteristics in general with a relatively high level of education and has quite good business experience. The technical competence of millennial farmers that stands out is in the ability to choose commodities based on the planting calendar, market demand, land fertility and land typology, while managerial competence that is lacking from millennial farmers is in terms of the ability to manage conflicts that can occur in their business development, while social competence as a social capital strength of millennial farmers is still weak.
\end{abstract}

Keywords: Character, farmer, millenial, regeneration

\begin{abstract}
ABSTRAK
Hadirnya petani milenial memberikan salah satu alternatif dalam mempercepat regenerasi petani. Petani milenial dianggap mampu menjembatani antara petani muda dengan petani yang telah lama berusahatani. Namun kecenderungan di lapangan belum terlihat karakter yang spesifik dimiliki oleh petani milenial. Tujuan penelitian ini adalah mendeskripsikan penciri utama petani milenial dan menganalisis faktor yang berpengaruh terhadap pembentukan karakter petani milenial. Penelitian menggunakan desain survei dengan teknik pengambilan sampel cluster random sampling, diperoleh 63 responden yang mewakili petani milenial pada zona sentra padi di tiga kabupaten (Subang, Karawang, dan Cirebon) di Jawa Barat. Pengolahan data menggunakan teknik deskriptif dan Partial Least Square. Hasil penelitian menunjukkan karakter petani milenial memiliki ciri individu umumnya dengan tingkat pendidikan yang relatif tinggi dan memiliki pengalaman berusahatani yang cukup baik. Kompetensi teknis petani milenial yang menonjol ada pada kemampuan dalam pemilihan komoditas berdasarkan kalendar tanam, permintaan pasar, kesuburan lahan dan tipologi lahan, sedangkan kompetensi manajerial yang kurang dari petani milenial adalah dalam hal kemampuan mengelola konflik yang dapat terjadi dalam pengembangan usahanya, sementara kompetensi sosial sebagai kekuatan modal sosial petani milenial masih lemah. Faktor yang memiliki pengaruh nyata positif dalam membentuk karakter petani milenial adalah ciri individu, kompetensi teknis dan kompetensi manajerial sedangkan kompetensi sosial memiliki pengaruh yang negatif.
\end{abstract}

Kata kunci: Karakter, milenial, petani, regenerasi

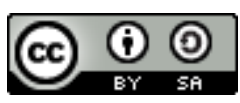

Content from this work may be used under the terms of the Creative Commons Attribution-ShareAlike 4.0 International. Any further distribution of this work must maintain attribution to the author(s) and the title of the work, journal citation and DOI.

Published under Department of Communication and Community Development Science, IPB University and in association with Perhimpunan Ahli Penyuluhan Pembangunan Indonesia.

E-ISSN: 2442-4110 | P-ISSN: 1858-2664 


\section{PENDAHULUAN}

Hasil Sensus Penduduk pada tahun 2020 mencatat, bahwa jumlah penduduk kategori milenial sebanyak 25.87 persen atau sekitar 69.901 juta dari jumlah penduduk 270.20 juta jiwa, artinya tenaga kerja produktif potensial cukup tersedia, lebih lagi saat ini Indonesia tengah menghadapi kelimpahan bonus demografi terkait dengan sumberdaya manusia. Sekitar 70.72 persen penduduk Indonesia saat ini berumur antara 15 - 64 Tahun (BPS, 2020). Namun, hasil penelitian KRKP (2015) melaporkan bahwa sebagian besar generasi muda menyatakan kondisi pertanian memprihatinkan, yang mengkibatkan sedikitnya generasi muda tergerak untuk bekerja di sektor pertanian. Rendahnya persepsi inilah yang menyebabkan rendahnya minat generasi muda pada bidang pertanian.

Hadirnya petani milenial yang digagas oleh Kementerian Pertanian memberikan salah satu alternatif dalam mempercepat regenerasi petani. Petani milenial dianggap mampu menjembatani antara petani muda dengan petani yang telah lama berusahatani. Namun kecenderungan di lapangan belum terlihat karakter yang spesifik dimiliki oleh petani milenial. Petani milenial masih dianggap sebagai pilihan kedua pekerjaan dan hanya label pada generasi muda yang bekerja sebagai petani.

Masyarakat menilai pertanian identik dengan kemiskinan sehingga sebagian besar generasi muda enggan melirik sektor pertanian sebagai mata pencaharian (Haryanto, 2021). Imbasnya adalah petani milenial sebagai individu yang telah berusaha di sektor pertanian dianggap sebagai individu yang kurang memberikan peranan dalam pembangunan pertanian. Hasil data BPS kajian KRKP tersebut bila tidak disikapi dengan bijak maka akan berdampak pada porsi petani di Indonesia yang terus menurun.

Pada umumnya, menjadi pelaku pertanian atau pelaku agribisnis bukanlah pilihan utama pemuda, termasuk pemuda perdesaan. Boleh jadi, keterlibatan pemuda dalam bertani dan atau beragribisnis lebih merupakan sebuah keterpaksaan. Walaupun faktanya tidak semua seperti itu dan yang seperti itupun dalam proses perjalanannya banyak yang berkembang melebihi pilihan utamanya (Haryanto, 2021). Terlepas dari semua itu, bahwasannya keputusan para pelaku muda untuk menentukan pilihan bertani atau beragribisnis sejatinya melalui proses atau tahapan-tahapan pengambilan keputusan (Gibbons dan Ramsden, 2008). Oleh karena itu, petani milenial dianggap sebagai individu yang telah melewati tahapan-tahapan tersebut sehingga seharusnya telah memiliki pendirian yang stabil untuk berkecimpung di sektor pertanian.

Karakter inilah yang diharapkan dari hadirnya petani milenial sehingga mampu menjadi pendorong para generasi muda lainnya untuk bekerja di sektor pertanian. Generasi muda di era ini perlu bukti dan contoh untuk mau, berminat dan tertarik bekerja di sektor pertanian (Haryanto, 2021). Kehadiran petani milenial yang merepresentatifkan petani masa kini dengan berjiwa muda, akses pasar relatif baik dan wirausahawan berhasil menjadi salah daya tarik agar generasi milenial ini mau berdaya saing dan berdaya sanding pada bidang pertanian. Hal ini juga menegaskan bahwa penyuluhan dari petani ke petani dengan figur petani milenial berhasil dapat menjadi katalisator yang baik dalam menarik generasi muda berminat bekerja di sektor pertanian. Meskipun hasil penelitian Anwarudin et al., (2020) mengemukakan bahwa petani muda atau milenial memiliki kecenderungan dengan pendidikan lebih baik dibanding petani dewasa, sebagian besar belum mengikuti pelatihan dan magang, sudah memiliki akses terhadap TIK, persepsi terhadap usaha pertanian dalam kategori sedang tetapi motivasinya masih rendah. Oleh karena itu, perlu dikaji secara mendalam terkait dengan karakter petani milenial yang mampu menjadi daya ungkit bagi pembangunan pertanian dan regenerasi petani khususnya yang berada di kawasan sentra padi.

Berdasarkan uraian tersebut, penelitian ini difokuskan untuk menentukan secara spesifik karakter yang melekat pada petani milenial agar diperoleh karakter baku bagi petani milenial yang mampu menjadi penarik generasi muda lainnya. Adapun tujuan dari penelitian ini adalah mendeskripsikan penciri utama petani milenial dan menganalisis faktor yang berpengaruh terhadap pembentukan karakter petani milenial.

\section{HASIL DAN PEMBAHASAN}

\section{Ciri Individu Petani Milenial}

Ciri individu petani milenial meliputi umur, pendidikan formal, luas lahan garapan yang dimiliki dan pengalaman berusahatani. Kondisi ciri individu petani milenial secara keseluruhan berada pada kategori 
tinggi, terutama di pendidikan formal dan pengalaman berusahtani. Hanya pada luas lahan garapan yang dikelola oleh para petani milenial rendah. Hal ini dikarenakan cukup beragamnya luasan yang dikelola oleh setiap individunya, meskipun jika melihat rataaan luas lahan garapan yang dikelola cukup tinggi yaitu 0,7 hektar. Fase umur petani milenial didominasi pada fase pertengahan kedewasaan. Selengkapnya ciri individu petani milenial pada Tabel 1.

Menurut Havighurst (1974) kelompok periode yang didasarkan pada umur manusia dewasa, yaitu: (1) umur 18-30 tahun adalah masa awal kedewasaan (early adulthood), (2) umur 30-60 tahun adalah masa pertengahan kedewasaan (middle age), (3) umur lebih dari 60 tahun adalah masa kematangan akhir/sangat dewasa (later maturity). Berdasarkan data yang diperoleh, diketahui bahwa umur responden sebagian besar $(74,6 \%)$ berada pada rentang umur pertengahan kedewasaan (middle age). Sebagian besar responden berada pada rentang umur produktif, sehingga responden dapat terlibat secara aktif dalam melakukan kegiatan usahatani dari hulu sampai hilir seperti pemilihan jenis tanaman, penyediaan bibit, penyediaan lahan, penanaman dan pemeliharaan. Hal ini sesuai dengan penelitian Putra et al. (2006), petani yang memiliki kemampuan fisik yang baik secara umum berada di rentang usia produktif. Pada usia-usia tersebut juga, biasanya seseorang dalam kondisi yang relatif produktif dalam bekerja dan banyak mencari peluang atau informasi yang menguntungkan bagi kegiatan-kegiatan yang berhubungan dengan peningkatan kesejahteraan dan pencarian prestise diri, yang kemudian diakhiri dengan rasa puas dalam diri atas keberhasilan yang diperolehnya. Dengan kondisi fisik yang baik, mereka dapat melakukan kegiatan secara optimal dan masih dapat mengembangkan kemampuan diri dalam hal berusahatani.

Tabel 1. Ciri Individu Petani Milenial

\begin{tabular}{lcc}
\hline \multicolumn{1}{c}{ Ciri Individu Petani Milenial } & Jumlah & Persentase \\
\hline Umur (tahun) & & \\
Awal Kedewasaan (18-30) & 16 & 25,4 \\
Pertengahan Kedewasaan (31-60) & 47 & 74,6 \\
$\quad$ Rataan = 34 tahun & & \\
Pendidikan Formal (tahun) & 3 & 4,8 \\
$\quad$ Rendah (2-9) & 60 & 95,2 \\
Tinggi (10-16) & & \\
Rataan $=14$ tahun & 37 & 58,7 \\
Luas Lahan Garapan (hektar) & 25 & 39,7 \\
$\quad$ Rendah (<0,5) & & \\
Tinggi (>0.5) & & 46,0 \\
Rataan $=0.7$ hektar & 29 & 54,0 \\
Pengalaman berusahatani (tahun) & 34 & \\
Rendah $(0-5)$ & & \\
Tinggi $(>5)$ & &
\end{tabular}

Usia petani milenial tersebut sesuai dengan pernyataan Lodismith dan Roberts (2010) yaitu usia mencerminkan berbagai pengalaman yang telah dijalaninya untuk menuju sukses dalam hidup dengan ukuran kompetensi, kebahagiaan, jiwa yang sehat dan pekerjaan. Kelompok usia pertengahan tersebut masih potensial untuk mengembangkan diri dan mengembangkan usahatani (Harijati, 2007). Oleh karena itu, usia yang cocok untuk mengembangkan diri dalam menjalankan dan mengelola usaha di bidang pertanian di era saat ini berada dikisaran usia pertengahan, sehingga diharapkan juga kiprahnya para petani milenial ini dapat menarik lebih banya petani muda lainya untuk mengatasi kekurangan tenaga muda pada sektor pertanian karena mampu menjadi contoh dalam keberhasilannya menjalankan usahatani.

Pendidikan formal merupakan capaian pendidikan yang pernah diikuti responden dalam bentuk tahun. Rataan pendidikan formal responden termasuk tinggi yaitu 14 tahun yaitu diatas lulusan Sekolah Menengah Atas. Pendidikan responden 95.2\% didominasi dengan pendidikan yang tinggi. Hal inilah yang membedakan dengan petani pada umumnya, kekhasan yang dimiliki oleh petani milenial salah satunya adalah memiliki pendidikan yang tinggi sehingga memiliki pengetahuan yang relatif baik dalam 
mengelola usahatani. Hasil penelitian yang dilakukan oleh Alonge et al. (2014) mengungkapkan bahwa pendidikan berhubungan dengan kemandirian individu. Hasil penelitian lainnya juga memperlihatkan pendidikan memiliki pengaruh pada kemampuan seseorang dalam menjalankan suatu pekerjaan (Subagio, 2008; Fatchiya, 2010; Yunita et al. 2012), sehingga dapat diartikan pendidikan merupakan suatu hal yang memiliki keterkaitan seseorang dalam berpikir dan bertindak sesuai dengan kapasitasnya.

Hasil penelitian ini berbeda dengan hasil penelitian Riana et al. (2015) dimana keterbatasan yang dimiliki para petani secara keseluruhan menyebabkan rendahnya pendidikan. Tingginya pendidikan formal petani milenial mampu mengurangi kekhawatiran akan kurang responnya petani dalam mengatasi tuntutan pasar terhadap produk usahatani. Hal ini karena petani milenial mampu berpikir secara rasional dan berwawasan luas sehingga mampu memproduksi dan menjaga kualitas produknya yang sesuai permintaan pasar, mampu melihat peluang pasar dan mencoba inovasi yang sesuai kebutuhannya, sekaligus dapat menularkannya kepada petani mitranya. Hal ini menjelaskan bahwa dukungan pendidikan yang memadai dapat memberikan pengaruh pada kemampuan seseorang dalam menjalankan suatu pekerjaan (Fatchiya, 2010; Yunita et al. 2012; Haryanto, 2018). Semakin tinggi tingkat pendidikan seseorang maka akan mempengaruhi cara berpikir, sikap dan perilakunya kearah yang lebih rasional dalam menerima dan memahami inovasi teknologi yang diperolehnya (Prawiranegara, 2016; Haryanto et al. 2018).

Luas lahan garapan yang dimiliki dan dikelola oleh petani milenial sebagian besar berada dalam kategori rendah. Hal ini dikarenakan sebagian besar petani milenial lebih cenderung berusahatani di hilir yang lebih pada aspek pengolahan dan pemasaran sehingga tidak memerlukan luas tanah yang besar. Namun demikian, rataan yang dimiliki untuk luas lahan garapan sebesar 0,7 hektar menggambarkan bahwa petani milenial sudah dapat keluar dari kategori petani gurem yang hanya memiliki atau mengelola luasan lahan garapan kurang dari 0.2 hektar. Hal ini menunjukkan bahwa petani milenial lebih adaptif terhadap perkembangan pertanian saat ini. Lamanya pengalaman berusahatani para petani milenial adalah satu tahun dan terlama 12 tahun. Rataan petani milenial memiliki pengalaman berusahatani yaitu 6 tahun. Lamanya pengalaman berusahatani akan berdampak pada cara pengambilan keputusan dalam menyelesaikan permasalahan-permasalahan dalam usahataninya. Semakin lama memiliki pengalaman usahatani maka pengalaman yang dimiliki tersebut dapat menjadi satu pertimbangan dalam pengambilan keputusan dan juga manfaat lainnya yang berguna untuk pengembangan usahatani. Sudarko (2010) mengemukakan hal yang sama yaitu semakin lama pengalaman usahatani dan berkelompok maka nilainilai usahatani dalam kelompok dan partisipasi dalam kegiatan kemasyarakatan semakin tinggi.

\section{Kompetensi Teknis}

Kompetensi teknis petani milenial merupakan kemampuan dasar yang diperlukan dalam menjalankan usaha, terdiri dari kemampuan dalam pemilihan komoditas berdasarkan kalendar tanam, permintaan pasar, kesuburan lahan dan tipologi lahan. Ketiga indikator kemampuan teknis petani milenial berada dalam kategori tinggi, hanya kemampuan teknis dalam pemilihan komoditas berdasarkan tipologi dengan kategori rendah. Selengkapnya sebaran nilai masing-masing indikator pada kompetensi teknis yang dimiliki petani milenial pada Tabel 2 .

Tabel 2. Kompetensi Teknis Petani Milenial

\begin{tabular}{lcc}
\hline \multicolumn{1}{c}{ Kompetensi Teknis } & Jumlah & Persentase \\
\hline Pemilihan komoditas berdasarkan kalender tanam & & \\
Rendah $(\leq 14)$ & 27 & 42,9 \\
Tinggi $(>14)$ & 36 & 57,1 \\
Rataan $=14$ & & \\
Pemilihan komoditas berdasarkan permintaan pasar & 24 & 38,1 \\
Rendah $(\leq 14)$ & 39 & 61,9 \\
Tinggi $(>14)$ & & \\
Rataan $=14$ & & 49,2 \\
Pemilihan komoditas berdasarkan kesuburan lahan & 31 & 50,8 \\
Rendah $(\leq 14)$ & 32 & \\
Tinggi $(>14)$ & &
\end{tabular}




\begin{tabular}{lcc}
\hline \multicolumn{1}{c}{ Kompetensi Teknis } & Jumlah & Persentase \\
\hline Pemilihan komoditas berdasarkan tipologi lahan & & \\
Rendah $(\leq 16)$ & 32 & 50,8 \\
Tinggi $(>16)$ & 31 & 49,2 \\
Rataan $=16$ & & \\
\hline Keterangan: $\mathrm{n}=63$ & &
\end{tabular}

Berdasarkan hasil kajian di lapangan, sebagian besar petani milenial di wilayah pantura yang didominasi oleh komoditas tanaman padi, belajar dari pengalaman dan melihat para petani lainnya dalam mengelola usahataninya. Sehingga, kemampuan teknis secara lebih mendalam baik dari segi budidaya, pengenalan jenis tanah, tipologi tanah dan lainnya yang secara teknis spesifik pertanian masih kurang. Pemahaman dan wawasan yang masih terbatas dalam memahami jenis dan tipologi lahan untuk berusahatani ini dikarenakan sebagian besar petani milenial tidak memiliki latar belakang pendidikan yang terkait dengan pertanian sehingga pengetahuannya berdasarkan pengalaman yang diperoleh dari kegiatannya mengelola usahatani. Hasil kajian ini selaras dengan Rachmat (2012) mengemukakan bahwa pengalaman adalah kepekaan untuk menafsir suatu objek, kejadian atau peristiwa yang dialami. Pengalaman tidak harus dilalui dengan proses belajar formal. Pengalaman akan bertambah dengan melalui rangkaian peristiwa yang pernah dihadapi. Semakin banyak peristiwa yang dihadapi, maka orang akan semakin peka terhadap peristiwa tersebut.

Pengalaman mencoba dan melakukan ini yang dapat terus mengasah kemampuan teknis sehingga sebagian besar indikator pada kompetensi teknis petani milenial ini berada dalam kategori tinggi. Hasil ini sejalan dengan Sumarlan et al., (2012) yang menyatakan bahwa dunia pertanian telah ditekuni petani sejak usia remaja, panjangnya pengalaman bertani menyebabkan petani dapat melihat dengan cermat dan teliti tentang hal-hal yang berkaitan dengan pengelolaan pertanian di lahan kritis. Oleh karena itu, kemampuan teknis wajib dimiliki oleh petani milenial sebagai karakter utama yang dapat diperoleh dari pengalamannya yang terus diasah dalam menjalankan usaha di bidang pertanian.

\section{Kompetensi Manajerial}

Kompetensi manajerial petani milenial adalah kemampuan merencanakan dan mengontrol usaha agar berjalan dengan lancar dan berhasil yang terdiri dari kemampuan mengelola usaha, mengelola jejaring kemitraan, mengelola sumberdaya, dan mengelola konflik. Berdasarkan hasil analisis deskriptif dari keempat indikator kompetensi manajerial petani milenial di daerah sentra padi terdapat satu indikator yang berada dalam kategori rendah yaitu pada indikator kemampuan dalam mengelola konflik, sedangkan ketiga indikator lainnnya kategori tinggi. Selengkapnya sebaran nilai masing-masing indikator pada kompetensi manajerial yang dimiliki petani milenial pada Tabel 3.

Tabel 3. Kompetensi Manajerial Petani Milenial

\begin{tabular}{|c|c|c|}
\hline Kompetensi Manajerial & Jumlah & Persentase \\
\hline \multicolumn{3}{|l|}{ Kemampuan Mengelola Usaha } \\
\hline Rendah $(<6)$ & 19 & 30,2 \\
\hline Tinggi $(>6)$ & 44 & 69,8 \\
\hline \multicolumn{3}{|l|}{ Rataan $=6$} \\
\hline \multicolumn{3}{|l|}{ Kemampuan Mengelola Jejaring Kemitraan } \\
\hline Rendah $(\leq 11)$ & 24 & 38,1 \\
\hline Tinggi $(>11)$ & 39 & 61,9 \\
\hline \multicolumn{3}{|l|}{ Rataan $=11$} \\
\hline \multicolumn{3}{|l|}{ Kemampuan Mengelola Sumberdaya } \\
\hline Rendah $(<14)$ & 23 & 36,5 \\
\hline Tinggi $(>14)$ & 40 & 63,5 \\
\hline \multicolumn{3}{|l|}{ Rataan $=14$} \\
\hline \multicolumn{3}{|l|}{ Kemampuan Mengelola Konflik } \\
\hline Rendah $(<19)$ & 33 & 52,4 \\
\hline Tinggi (> 19) & 30 & 47,6 \\
\hline Rataan $=19$ & & \\
\hline
\end{tabular}

Keterangan: $\mathrm{n}=63$ 
Berdasarkan hasil kajian ditemukan bahwa kelemahan pada aspek kompetensi manajerial petani milenial adalah dalam hal kemampuan mengelola konflik baik dari internal dirinya sendiri ataupun eksternal yang berkaitan dengan lingkungan usahatani. Hal ini dikarenakan dari sisi usia petani milenial memiliki kecenderungan pada usia yang relatif masih muda sehingga seringkali tidak berpikir panjang dalam mengambil keputusan. Hal ini berdampak pada besarnya konflik yang akan timbul dari keputusan yang diambil tersebut. Oleh karena itu, petani milenial terutama pada sentra padi memerlukan mentor dalam mendampingi usahataninya sehingga keputusan yang diambil telah memperoleh masukanmasukan dari mentor pendampingnya. Mentor dapat berasal dari penyuluh pertanian setempat atau pelaku usaha yang menjadi mitra dari petani milenial tersebut. Pengelolaan konflik identik dengan proses kemandirian dari petani milenial tersebut sehingga menjadi lebih matang dalam bertindak untuk mengembangkan usahanya.

Abas (2016) dan Emery (2014) mengungkapkan bahwa kemandirian petani merupakan proses yang relatif panjang, terutama pada para petani yang memiliki pendidikan rendah. Hal ini diperkuat oleh Abas (2016) bahwa semakin tinggi tingkat pendidikan petani, mereka akan semakin menjadi pemikir independen. Kemandirian petani dapat terjadi karena adanya kerjasama antara sesama petani dan organisasi petani yang berjalan dengan baik (Niska et al. 2012 ; Sutherland dan Burton 2011; Emery dan Franks, 2012 ; dan Emery, 2014). Kemandirian petani dipengaruhi oleh kemampuan manajerial, kemampuan sosial dan keinovatifan yang dimiliki (Idoma dan Muhammad, 2013; Ruhimat, 2014). Oleh karena itu, peran pemerintah masih dibutuhkan untuk meningkatkan kemampuan petani milenial terutama melalui pendidikan non formal sehingga dapat menjadi pribadi yang inovatif (Utami dan Sumardjo, 2006; Idoma dan Muhammad, 2013).

\section{Kompetensi Sosial}

Kompetensi sosial merupakan kemampuan melibatkan diri dalam kegiatan kemasyarakat dalam hal pendidikan, ekonomi, organisasi dan pembangunan pertanian. Berdasarkan hasil analisis deskriptif dari keempat indikator kompetensi sosial petani milenial di daerah sentra padi terdapat hanya satu indikator yang berada dalam kategori tinggi yaitu pada indikator keterlibatan dalam pengembangan masyarakat pada aspek ekonomi, sedangkan ketiga indikator lainnnya kategori rendah. Selengkapnya sebaran nilai masing-masing indikator pada kompetensi sosial yang dimiliki petani milenial pada Tabel 4.

Tabel 4. Kompetensi Sosial Petani Milenial

\begin{tabular}{lcr}
\hline \multicolumn{1}{c}{ Kompetensi Sosial } & Jumlah & Persentase \\
\hline Keterlibatan dalam Pengembangan Masyarakat pada Aspek Pendidikan & & \\
$\quad$ Rendah $(\leq 11)$ & 36 & 57,1 \\
$\quad$ Tinggi $(>11)$ & 27 & 42,9 \\
$\quad$ Rataan $=11$ & & \\
Keterlibatan dalam Pengembangan Masyarakat pada Aspek Ekonomi & & \\
$\quad$ Rendah $(\leq 11)$ & 29 & 46,0 \\
$\quad$ Tinggi $(>11)$ & 34 & 54,0 \\
$\quad$ Rataan $=11$ & & \\
Keterlibatan dalam Pengembangan Masyarakat pada Aspek Organisasi & & \\
$\quad$ Rendah $(\leq 11)$ & 32 & 50,8 \\
$\quad$ Tinggi $(>11)$ & 31 & 49,2 \\
$\quad$ Rataan $=11$ & & \\
Keterlibatan dalam Pengembangan Program Pembangunan Pertanian & & \\
$\quad$ Rendah $(\leq 11)$ & 33 & \\
$\quad$ Tinggi $(>11)$ & 30 & \\
$\quad$ Rataan $=11$ & & \\
\hline Keterangan: $\mathrm{n}=63$ & &
\end{tabular}

Keterlibatan dalam pengembangan masyarakat terutama pada aspek pendidikan, oganisasi dan pembangunan pertanian yang merupakan indikator kompetensi sosial berkategori rendah yang dimiliki oleh petani milenial di sentra padi. Hal ini dikarenakan sebagian besar petani milenial belum terafiliasi pada kelembagaan petani atau Pusat Pelatihan Pertanian Pedesaaan Swadaya, sehingga petani milenial belum memiliki wadah untuk berbagi pengetahuan dan keterampilan kepada petani lainnya serta 
berorganisasi dengan sesama petani. Selain itu, fokus kegiatan petani milenial kecenderungan untuk mengembangkan usahatani sehingga kompetensi sosial yang menonjol adalah keterlibatan dalam mengembangkan masyarakat pada aspek ekonomi dengan mengajak dan memberdayakan generasi muda di sekelilingnya untuk membantu dan terlibat dalam usahatani.

Oleh karena itu, petani milenial berdasarkan hasil kajian ini belum dapat dijadikan sebagai pendamping yang kuat untuk mendampingi para petani karena belum memenuhi syarat sebagai pendamping. Menurut Zedadra et al., (2019) peran pendamping umumnya mencakup empat peran utama, yaitu: fasilitator, pendidik, perwakilan masyarakat, dan peran-peran teknis bagi masyarakat miskin yang didampinginya. Petani milenial masih rendah memainkan perannya sebagai pendidik dan peran teknis lainnya sehingga masih memerlukan pelatihan dan pendampingan serta keterlibatan pemerintah untuk memperkuat kompetensi sosial petani milenial.

Kompetensi sosial sebagai dasar modal sosial muncul dari pemikiran bahwa anggota masyarakat tidak mungkin dapat secara individu mengatasi berbagai masalah yang dihadapi sehingga diperlukan adanya kebersamaan dan kerjasama yang baik dari segenap anggota masyarakat yang berkepentingan untuk mengatasi masalah tersebut (Syahra, 2003). Modal sosial merupakan aset yang dihasilkan ketika orang berinteraksi, menciptakan hubungan kepercayaan dan pemahaman umum (Gotschi et al. 2008). Menurut Sobel (2002) modal sosial menggambarkan keadaan di mana individu dapat menggunakan keanggotaan dalam kelompok dan jaringan untuk mengamankan manfaat. Berdasarkan hal tersebut petani milenial khususnya di daerah sentra padi perlu meningkatkan interaksi yang lebih intens lagi dengan tokoh-tokoh masyarakat dan organisasi sosial yang ada di pedesaan untuk memperkuat kompetensi sosial tersebut.

\section{Faktor yang Mempengaruhi Karakter Petani Milenial dan Dampaknya terhadap penumbuhan Petani Milenial Baru}

Karakter Petani Milenial diduga dipengaruhi oleh faktor seperti ciri individu, kompetensi teknis, kompetensi manajerial dan kompetensi sosial. Hasil pengujian PLS mempelihatkan bahwa model memiliki pengaruh antara ciri individu, komptensi teknis, kompetensi manajerial dan kompetensi sosial terhadap karakter petani milenial. Peubah yang menunjukkan paling besar pengaruhnya adalah kompetensi teknis dan kompetensi sosial. Model pengukuran (outer model) disajikan pada Gambar 1.

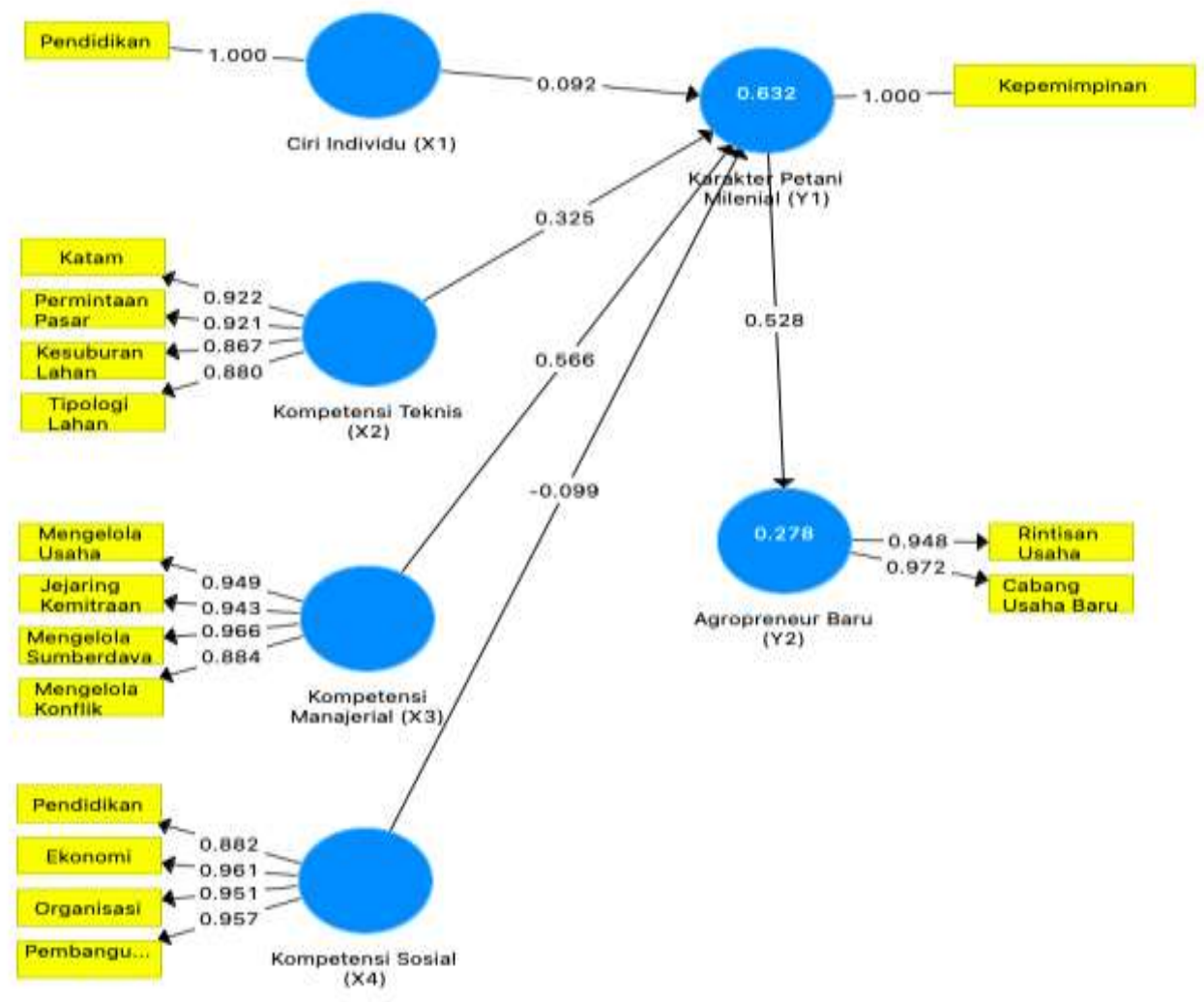

Gambar 1. Model Pengukuran (outer model) 
Ciri individu yang terdiri dari umur, pendidikan formal, luas lahan garapan dan lama pengalaman berusahatani, hasil penelitian menunjukkan terdapat dua indikator yang memiliki pengaruh nyata dan langsung yaitu pendidikan dan luas lahan. Hal ini menunjukkan bahwa ciri individu petani milenial sangat dominan dengan pendidikan yang tinggi dan berani mengambil resiko dalam berusaha tani dalam hal ini adalah penguasaan lahan garapan yang luas. Hal ini selaras dengan penelitian yang telah dilakukan oleh Haryanto dan Yuniarti, (2017) dan Yuniarti et al. (2020), bahwa tokoh petani maju/milenial dan petani terkategori "brain gain" memiliki pendidikan yang tinggi dan mampu bersaing dengan dinamika perubahan pola budidaya tanaman yang cenderung dikelola moderen, luas dan pemasaran yang jelas. Ciri individu petani milenial ini merupakan penguat bahwa setiap petani milenial harus memiliki minimal dua indikator ini sehingga usaha yang dijalankannya mampu bertahan lama dan resonansi yang diberikan pada lingkungan sekitar terutama anak-anak muda menjadi lebih besar sehingga semakin banyak generasi milenial tertarik pada sektor pertanian. Meskipun luas lahan garapan tidak masuk dalam model hasil PLS, namun kondisi dilapangan luas lahan garapan ini merefleksikan performa dari ciri individu petani milenial sehingga sangat berpengaruh dalam menjalan suatu usahatani.

Kompetensi teknis yang terdiri dari pemilihan komoditas berdasarkan kalender tanam, permintaan pasar, kesuburan lahan dan tipologi lahan, hasil penelitian menunjukkan keempat indikator memiliki pengaruh nyata dan langsung. Keempat indikator tersebut juga memiliki nilai factor loading di atas 0,7 yaitu $0,922,0,921,0,867$ dan 0,880 sehingga indikator tersebut mampu merefleksikan kompetensi teknis yang dimiliki oleh petani milenial. Hal ini juga menunjukkan bahwa petani milenial seorang yang pembelajar sehingga sangat mudah beradaptasi dengan situasi sehingga kompetensi teknis terus terasah dan belajar dari pengalaman-pengalaman yang didapatnya selama mengelola usahatani. Hal ini sejalan dengan penelitian Haryanto, (2018), yang menggambarkan petani milenial/maju memiliki kecenderungan seorang pembelajar dan senantiasa meningkatkan kemampuannya dalam hal pengembangan usahanya.

Kompetensi manajerial yang terdiri dari kemampuan dalam hal mengelola usaha, jejaring kemitraan, mengelola sumberdaya yang dimiliki dan mengelola konflik. Hasil penelitian juga menunjukkan bahwa keempat indikator memiliki pengaruh nyata dan langsung. Keempat indikator tersebut juga memiliki nilai factor loading di atas 0,7 yaitu 0,949, 0,943, 0,966 dan 0,884 sehingga indikator tersebut mampu merefleksikan kompetensi manajerial yang dimiliki oleh petani milenial. Kompetensi manajerial indentik dengan kepemimpinan yang dimiliki oleh petani milenial. Hal ini menunjukkan bahwa meskipun milenial tetapi petani milenial memiliki kemampuan kepemimpinan yang baik dalam mengelola usahatani dan berjejaring dengan mitra lain untuk mendukung usahatani. Kepemimpinan dalam mengelola manajemen usahatani ini merupakan penciri khas dari petani maju dan milenial. Hasil ini selaras dengan penelitian Suyadi dan Rimbawati, (2020) dan Rimbawati et al. (2018) bahwa kepemimpinan yang baik dari seorang invididu dapat mencerminkan kemampuannya dalam mengelola suatu usaha dan penciri pribadi yang spesifik.

Kompetensi sosial yang terdiri dari pengembangan masyarakat pada aspek pendidikan, aspek ekonomi, aspek organisasi dan pembangunan pertanian. Hasil penelitian juga menunjukkan bahwa keempat indikator memiliki pengaruh nyata dan langsung. Keempat indikator tersebut juga memiliki nilai factor loading di atas 0,7 yaitu 0,882, 0,961, 0,951 dan 0,957 sehingga indikator tersebut mampu merefleksikan kompetensi sosial yang dimiliki oleh petani milenial.

Salah satu kekuatan yang dimiliki oleh petani milenial adalah kemampuannya dalam memberikan motivasi kepada lingkungan sekitarnya terutama generasi muda dalam bentuk contoh secara langsung. kompetensi sosial sebagai salah satu modal sosial yang dimiliki oleh petani milenial tergambar dari kemampuannya mengorganisasikan kegiatan masyarakat. Beberapa petani milenial di daerah penelitian bahkan memiliki komunitas tersendiri sebagai bagian jejaring dan kemitraannya sehingga hal ini mampu menggerakkan perekonomian di desanya. Hasil penelitian sejalan dengan Haryanto, (2018); Yuniarti et al. (2020) dan Setiawan et al, (2015) yaitu petani maju dan milenial memliki modal sosial yang tinggi sehingga secara tidak langsung menjadi sumber kemampuan sosialnya dalam mengelola, menggerakan dan menjadi contoh kegiatan usaha di wilayahnya.

Berdasarkan keempat indikator yang mempengaruhi karakter petani milenial yaitu ciri individu, kompetensi teknis, kompetensi manajerial dan kompetensi sosial, menunjukkan bahwa keempat indikator tersebut menjadi penciri karakter petani milenial yang kuat dan harus dimiliki untuk dapat menjadi triger dalam menggerakkan percepatan regenerasi petani. Hasil analisis PLS menunjukkan bahwa faktor yang berpangaruh terhadap karakteristik petani milenial yaitu ciri individu, kompetensi teknis dan kompetensi manajerial berpengaruh positif, sedangkan kompetensi sosial berpengaruh 
negatif. Hal ini mengindikasikan bahwa kompetensi sosial menjadi salah satu penciri karakter yang tidak terlalu dominan dalam mencerminkan petani milenial tetapi kekuatan teknis, manajerial dan individulah yang menjadi keunggulan petani milenial. Meskipun demikian, kemampuan sosial perlu dimiliki untuk menunjang jejaring dan menggerakkan masyarakat khususnya generasi muda untuk ikut terjun ke dalam sektor pertanian.

Dampak dari karakter petani milenial ini adalah diharapkan adanya resonansi dan penumbuhan agropreneur-agropreneur baru. Berdasarkan hasil PLS, menunjukkan bahwa karakter petani milenial memiliki pengaruh positif yang kuat terhadap lahirnya agropreneur baru. Hasil penelitian ini selaras dengan penelitian yang dilakukan Anwarudin dan Haryanto, (2018); Yuliani dan Sulaeman, (2012); Kiptot dan Franzel, (2014) yang mengungkapkan bahwa karakteristik yang ulet dan teladan dari petani maju sebagai bagian dari komunitas masyarakat dapat memberi contoh dan dorongan secara langsung atau tidak langsung kepada generasi muda untuk melakukan usaha yang sama di bidang pertanian. Petani milenial memiliki modal sosial dalam memberikan motivasi kepada generasi muda pertanian untuk dapat berusaha di bidang pertanian sebagai bagian dari regenerasi pelaku pertanian. Namun, hasil penelitian ini agak sedikit berbeda dengan Anwarudin et al., (2020) yang menyatakan kecenderungan petani milenial memiliki motivasi usaha yang rendah. Hal ini dikarenakan, petani milenial di kawasan sentra padi memiliki jejaring informasi yang kuat melalui modal sosial sehingga motivasi untuk mengembangkan usaha relatif tinggi.

\section{KESIMPULAN}

Karakter petani milenial di sentra padi memiliki ciri individu umumnya dengan tingkat pendidikan yang relatif tinggi dan memiliki pengalaman berusaha tani yang cukup baik. Kompetensi teknis petani milenial yang menonjol ada pada kemampuan dalam pemilihan komoditas berdasarkan kalendar tanam, permintaan pasar, kesuburan lahan dan tipologi lahan, sedangkan kompetensi manajerial yang kurang dari petani milenial adalah dalam hal kemampuan mengelola konflik yang dapat terjadi dalam pengembangan usahanya. Kompetensi sosial sebagai kekuatan modal sosial petani milenial masih lemah, hanya tercermin dari keterlibatan dalam mengembangkan masyarakat pada aspek ekonomi dengan mengajak dan memberdayakan generasi muda di sekelilingnya untuk membantu dan terlibat dalam usahatani. Faktor yang memiliki pengaruh nyata positif dalam membentuk karakter petani milenial adalah ciri individu, kompetensi teknis dan kompetensi manajerial sedangkan kompetensi sosial memiliki pengaruh yang negatif. Namun demikian, keempat indikator tersebut menjadi penciri karakter petani milenial yang kuat dan harus dimiliki untuk dapat menjadi triger dalam menggerakkan percepatan regenerasi petani.

\section{DAFTAR PUSTAKA}

Abas, M. S. (2016). Factors influencing self-reliance in rice production, the case of small farmers in Bataan, Philippines. International Journal of Agricultural Technology, 12(1), 41-53.

Alonge, H. O., IGE, A. M., \& Osagiobare, O. E. (2014). Women Empowerment For Self-Reliance: Educational Management Strategies in Nigeria Case. Journal of Educational and Social Research, 4(1), 517-524. https://doi.org/10.5901/jesr.2014.v4n1p517

Anwarudin, O., \& Haryanto, Y. (2018). The role of farmer-to-farmer extension as a motivator for the agriculture young generation. International Journal of Social Science and Economic Research, 3(1), 428-437.

Anwarudin, O., Sumardjo, S., Satria, A., \& Fatchiya, A. (2020). The Entrepreneurial Capacity of Young Farmers on Agribusiness Activities in West Java. Jurnal Penyuluhan, 16(2), 267-276. https://doi.org/10.25015/16202031039

BPS. (2020). Hasil Sensus Penduduk. Jakarta.

Darmawan. (2013). Metode Penelitian Kuantitatif. Bandung: Remaja Rosdakarya.

Emery, S. B. (2014). Independence and individualism: conflated values in farmer cooperation? Agriculture and Human Values, 32(1), 47-61. https://doi.org/10.1007/s10460-014-9520-8

Emery, S. B., \& Franks, J. R. (2012). The potential for collaborative agri-environment schemes in England: Can a well-designed collaborative approach address farmers' concerns with current schemes? Journal of Rural Studies, 28(3), 218-231. https://doi.org/10.1016/j.jrurstud.2012.02.004

Jurnal Penyuluhan | Vol. 18 (01) 2022 | 33 
Fatchiya A. (2010). Tingkat Kapasitas Pembudidaya Ikan dalam Mengelola Usaha Aquakultur secara Berkelanjutan. Penyuluhan, 6(1), 11-18.

Gibbons, J. M., \& Ramsden, S. J. (2008). Integrated modelling of farm adaptation to climate change in East Anglia, UK: Scaling and farmer decision making. Agriculture, Ecosystems and Environment, 127(1-2), 126-134. https://doi.org/10.1016/j.agee.2008.03.010

Gotschi, E., Njuki, J., \& Delve, R. (2008). Gender equity and social capital in smallholder farmer groups in Mozambique. Journal Development in Practice, 18(4), 650-657. https://doi.org/10.1080/09614520802181970

Harijati. (2007). Potensi dan Pengembangan Kompetensi Agribisnis Petani Berlahan Sempit: Kasus Petani Sayuran di Kota Pinggiran Jakarta dan Bandung. Institut Pertanian Bogor.

Haryanto, Y. (2018). Penguatan Kapasitas dan Kemandirian Tokoh Petani Maju sebagai Penyuluh Swadaya. IPB.

Haryanto, Y. (2021). PROGRESSIVE FARMERS AS CATALYSTS FOR REGENERATION IN RURAL AREAS THROUGH FARMER TO FARMER EXTENSION APPROACH. 867-874. https://doi.org/10.51470/PLANTARCHIVES.2021.v21.no1.120

Haryanto, Y., Sumardjo, S., Amanah, S., \& Tjitropranoto, P. (2018). Farmer to Farmer Extension Through Strengthening Progressive Farmers Role. International Journal of Progressive Sciences and Technologies (IJPSAT), 6(2), 228-234.

Haryanto, Y., \& Yuniarti, W. (2017). The Role of Farmer to Farmer Extension for Rice Farmer Independence in Bogor. International Journal of Research in Social Sciences, 7(4), 62-74. Diambil dari ijssr: https://www.ijmra.us/2017ijrss_april.php

Havighurst. (1974). Development Tasks and Education (Third Edit). New York (US): David McKay Company In.

Idoma, K., \& Muhammad, I. (2013). Self-Reliance: Key to Sustainable Rural Development in Nigeria. ARPN Journal of Science and Technology, 3(6), 585-592. Diambil dari http://www.ejournalofscience.org/archive/vol3no6/vol3no6_3.pdf

Kiptot, E., \& Franzel, S. (2014). Voluntarism as an investment in human, social and financial capital: Evidence from a farmer-to-farmer extension program in Kenya. Agriculture and Human Values, 31(2), 231-243. https://doi.org/10.1007/s10460-013-9463-5

KRKP. (2015). Laporan Kajian Regenerasi Petani. Jakarta.

Lodismith. Roberts W. (2010). Getting to Know Me: Social Role Experiences and Age Differences in Self-Concept Clarity During Adulthood. Journal of Personality, 78(5), 1384-1410. https://doi.org/10.1111/j.1467-6494.2010.00655.x

Niska, M., Vesala, H. T., \& Vesala, K. M. (2012). Peasantry and Entrepreneurship As Frames for Farming: Reflections on Farmers' Values and Agricultural Policy Discourses. Sociologia Ruralis, 52(4), 453-469. https://doi.org/10.1111/j.1467-9523.2012.00572.x

Prawiranegara. (2016). Penguatan peran kelembagaan petani dalam peningkatan kapabilitas petani mengelola inovasi berbasis teknologi informasi. Institut Pertanian Bogor.

Putra IGSA, Asngari PS, T. P. (2006). Dinamika Petani dalam Beragribisnis Salak (Kasus di Kabupaten Karangasem Provinsi Bali). Penyuluhan, 2(1), 44-52.

Rachmat, J. (2012). Psikologi Komunikasi. Bandung: Remaja Rosdakarya.

Riana, Satria, A., \& Purnaningsih, N. (2015). The Role of Self-Support Extension Agents in Supporting Intensification Cocoa in Sigi District Central Sulawesi. Jurnal Penyuluhan, 11(2), 201-211.

Rimbawati, D. E. manggala, Fatchiya, A., \& Sugihen, B. G. (2018). Dinamika Kelompok Tani Hutan Agroforestry di Kabupaten Bandung. Jurnal Penyuluhan, 14(1). https://doi.org/10.25015/penyuluhan.v14i1.17223

Ruhimat S. (2014). Faktor-Faktor Untuk Peningkatan Kemandirian Petani Dalam Pengelolaan Hutan Rakyat: Studi Kasus Di Desa Ranggang, Kabupaten Tanah Laut, Kalimantan Selatan. Jurnal Penelitian Sosial dan Ekonomi Kehutanan, 11(3), 237-249. https://doi.org/10.20886/jsek.2014.11.3.237-249

Setiawan, I., Sumardjo, S., Satria, A., \& Tjitropranoto, P. (2015). Strategi Pengembangan Kemandirian Pelaku Muda Agribisnis "Brain Gain Actors" di Jawa Barat. MIMBAR, Jurnal Sosial dan 
Pembangunan, 31(2), 409. https://doi.org/10.29313/mimbar.v31i2.1491

Sobel, J. (2002). Can we trust social capital. Journal of Economic Literature, 40, 139-154. https://doi.org/10.1257/0022051027001

Subagio. (2008). Peranan kapasitas petani dalam mewujudkan keberhasilan usaha tani: Kasus Petani Sayuran dan Padi di Kabupaten Malang dan Pasuruan Propinsi Jawa Timur. Institut Pertanian Bogor.

Sudarko. (2010). Hubungan Dinamika dan Peran Kelompok dengan Kemampuan Anggota dalam Penerapan Inovasi Teknologi Usaha Tani Kopi Rakyat (Kasus di Desa Sidomulyo Kecamatan Silo Kabupaten Jember Jawa Timur). Institut Pertanian Bogor.

Sumardjo. (1999). Transformasi model penyuluhan pertanian menuju pengembangan kemandirian petani (Kasus di Propinsi Jawa Barat) [disertasi]. 1-372.

Sumarlan, Sumardjo, Tjitropranoto P, dan G. D. (2012). Peningkatan kinerja petani sekitar hutan dalam penerapan sistem agroforestri di pegunungan kendeng Pati. Agro Ekonomi, 30(1), 25-39.

Sutherland, L. A., \& Burton, R. J. F. (2011). Good farmers, good neighbours? The role of cultural capital in social capital development in a Scottish farming community. Sociologia Ruralis, 51(3), 238255. https://doi.org/10.1111/j.1467-9523.2011.00536.x

Suyadi, \& Rimbawati, D. (2020). Peran kepemimpinan tokoh informal terhadap kemandirian kelompok tani hutan. Komunity Online, 1(2), 135-141.

Syahra, R. (2003). Modal Sosial: Konsep dan Aplikasi. Jurnal Masyarakat dan Budaya, 5(1), 1-22.

Utami, \& Sumardjo. (2006). Faktor-Faktor yang Berhubungan dengan Kemandirian Pengrajin Kulit di Kabupaten Sidoarjo dan Magetan, Jawa Timur. Penyuluhan, 2(4), 42-50.

Yuliani, S. S., \& , Munandar Sulaeman, dan S. W. (2012). HUBUNGAN ANTARA KARAKTERISTIK PENYULUH SWADAYA DENGAN MOTIVASI PETERNAK SAPI PERAH. Jurnal Unpad, 1.

Yuniarti, W., Sumardjo, Widiatmaka, \& Wibawa, W. D. (2020). Brain gain actors: Farmers' regeneration in Indonesia. Journal of Human Ecology, 71(1-3), 139-146. https://doi.org/10.31901/24566608.2020/71.1-3.3253

Yunita, Sugihen, B. G., Asngari, P. S., Susanto, D., \& Amanah, S. (2012). Strategi Peningkatan Kapasitas Rumah Tangga Petani Padi Sawah Lebak Menuju Ketahanan Pangan Rumah Tangga (Kasus di Kabupaten Ogan Ilir dan Ogan Komering Ilir, Sumatera Selatan) The Strategy for Increasing of Lowland Rice Household Farmers Capacity Towards. Jurnal Penyuluhan, 8(1). Diambil dari http://download.portalgaruda.org/article.php?article=268142\&val=7100\&title=The Strategy for Increasing of Lowland Rice Household Farmers Capacity Towards Households Food Security

Zedadra, O., Guerrieri, A., Jouandeau, N., Seridi, H., Fortino, G., Spezzano, G., ... Thesis, A. (2019). No 主観的健康感を中心とした在宅高齢者における 健康関連指標に関する共分散構造分 析Title. Sustainability (Switzerland), 11(1), 1-14. 